\title{
Sprawozdanie z VIII Kongresu Inicjatyw Europy Wschodniej. Linia programowa „Polityka i bezpieczeństwo"
}

K ongres Inicjatyw Europy Wschodniej w Lublinie na stałe wpisał się do kalendarza ważnych wydarzeń jako platforma dialogu i wymiany doświadczeń, która skupia ekspertów, naukowców, twórców, działaczy samorządowych i państwowych, praktyków współpracy transgranicznej oraz decydentów z kilku krajów. W trakcie Kongresu dzielą się oni swoimi doświadczeniami i wiedzą, analizują przeszłość i teraźniejszość oraz dyskutują o możliwych scenariuszach rozwoju wydarzeń w tej części Europu. Tegoroczna edycja Kongresu, która odbyła się w dniach 23-24 września 2019 r. w Lublinie, zbiegła się z takimi ważnymi rocznicami, jak 450-lecie Unii Lubelskiej, 20-lecie Polski w NATO oraz 15-lecie Partnerstwa Wschodniego, co znalazło swoje odzwierciedlenie również w programie wydarzenia. Niezwykłym akcentem na rozpoczęcie Kongresu był happening historyczny „Żywy obraz Unii Lubelskiej Jana Matejki”, w którym udział wzięli nie tylko aktorzy teatralni i artyści, ale również przedstawiciele urzędów z Polski i Ukrainy.

W ramach Kongresu rokrocznie odbywa się linia programowa „Polityka i bezpieczeństwo", której pomysłodawcą i organizatorem jest Centrum Europy Wschodniej UMCS. W VIII edycji Kongresu wspólnie z Wydziałem Politologii UMCS, Instytutem Europy Środkowej oraz Instytutem Nauk Politycznych i Spraw Międzynarodowych KUL Centrum Europy Wschodniej zorganizowało trzy panele dyskusyjne w ramach wspomnianej linii programowej. Tematem przewodnim tym razem była „Europa Wschodnia. Transformacja, integracja, bezpieczeństwo”.

Pierwszy panel „Europa Wschodnia między euroazjatyckim a europejskim modelem ustrojowym” moderował dyrektor Centrum Europy Wschodniej, prof. dr hab. Walenty Baluk. Do grona panelistów zaproszono przedstawicieli takich krajów, jak Gruzja (prof. dr. hab. Alexandre Kukhianidze z Tbiliskiego Uniwersytetu Państwowego), Federacja Rosyjska (prof. Paul' Kalinichenko z Wyższej Szkoły Ekonomicznej w Moskwie) 
i Ukraina (prof. dr. hab. Jurij Makar z Czerniowieckiego Uniwersytetu Narodowego im. J. Fed'kowycza, prof. dr. hab. Serhij Danyłenko z Kijowskiego Uniwersytetu Narodowego im. T. Szewczenki). Ponadto w panelu uczestniczył dr hab. Wojciech Sokół, prof. nadzw. UMCS z Wydziału Politologii. W trakcie tego panelu uczestnicy skupili się na takich zagadnieniach, jak: euroazjatycki a europejski model ustrojowy (autorytaryzm $v s$ demokracja); ocena zmian ustrojowych w państwach EW (hybrydowość rozwiązań ustrojowych); stabilność, rozwój i funkcyjność nowych państw EW; interesy państw Zachodu a demokracja w państwach EW w kontekście rywalizacji Wschodu z Zachodem i innych. Wystąpienia panelistów spotkały się z dużym zainteresowaniem oraz zaowocowały ciekawą dyskusją merytoryczną.

Drugi panel nosił tytuł „Europa Wschodnia między integracją europejską a euroazjatycką" i został zorganizowany przy wsparciu finansowym Fundacji Konrada Adenauera w Polsce. Panel był poświęcony 10-leciu Partnerstwa Wschodniego, a jego moderatorem została dr hab. Beata Piskorska z Instytutu Nauk Politycznych i Spraw Międzynarodowych KUL. W panelu tym uczestniczyli również przedstawiciele kilku krajów, w tym: Ambasador RP na Białorusi Artur Michalski, dr hab. Paweł Kowal z Instytutu Nauk Politycznych PAN, prof. dr hab. Anatolij Krugłaszow z Czerniowieckiego Uniwersytetu Narodowego im. Jurija Fed'kowycza, doc. dr Ołena Dobrżanśka z Kijowskiego Uniwersytetu Narodowego im. T. Szewczenki oraz ekspert ds. Białorusi dr Paweł Usow z Centrum Analiz i Prognoz Politycznych. Przedmiotem dyskusji uczestników był głównie bilans 10 lat funkcjonowania Partnerstwa Wschodniego z perspektywy Unii Europejskiej i państw beneficjentów. W trakcie wystąpień paneliści przeanalizowali, jak Partnerstwo Wschodnie wpłynęło na sytuację wewnętrzną objętych nim państw oraz jaka perspektywa czeka PW (czy program ulegnie stagnacji, czy ma szanse na rozwój). Uczestnicy dyskutowali również o wyborze przez państwa PW określonego modelu gospodarczego (zachodniego lub euroazjatyckiego). Ponadto rozważano, jakie są nowe wizje, idee, ze szczególnym uwzględnieniem przybliżania prawa, instytucjonalizacji i współpracy sektorowej; jakie są oczekiwania i interesy państw PW co do form współpracy z UE, jeśli w grę nie wchodzi członkostwo w UE w najbliższej perspektywie itp. Na zakończenie tego panelu dyrektor Centrum Europy Wschodniej prof. dr hab. Walenty Baluk wręczył Medal śś. Cyryla i Metodego dr. hab. Pawłowi Kowalowi, który został mu przyznany w czerwcu 2019 r. przez Radę Naukową CEW w uznaniu jego zasług dla współpracy polsko-ukraińskiej i stosunków dobrosąsiedzkich pomiędzy Polską a Ukrainą.

W trzecim panelu, którego moderatorem był dr Jakub Olchowski z Wydziału Politologii UMCS i Instytutu Europy Środkowej, toczyły się dyskusje o „Europie Wschodniej między euroatlantycką a euroazjatycką przestrzenią bezpieczeństwa”. W gronie uczestników znaleźli się: dr doc. Witalij Lebediuk z Narodowego Uniwersytetu „Akademia Ostrogska", dr doc. Roman Petiur z Instytutu Stosunków Międzynarodowych Kijowskiego Uniwersytetu Narodowego im. T. Szewczenki, prof. dr hab. Valentina Teosa z Mołdawskiego Uniwersytetu Państwowego oraz Stanisław Mitrachowicz z Narodowego Centrum Energetycznego z Rosji. Paneliści poszukiwali odpowiedzi na py- 
tania: czy zasadna jest teza o kształtowaniu się dwóch konkurencyjnych wizji systemu bezpieczeństwa europejskiego, i jeśli tak, jakie będzie to miało znaczenie dla globalnych procesów bezpieczeństwa, na ile nietradycyjne (pozamilitarne) wymiary bezpieczeństwa będą kształtować w przewidywalnej przyszłości architekturę bezpieczeństwa europejskiego, czy państwa Europy Środkowej i Wschodniej będą podmiotami polityki bezpieczeństwa, czy ich rola zostanie zmarginalizowana przez kolejny „koncert mocarstw" oraz czy Europie Wschodniej grożą konflikty zbrojne?

Poświęcona transformacji, integracji i bezpieczeństwu w Europie Wschodniej linia programowa „Polityka i bezpieczeństwo” cieszyła się sporym zainteresowaniem ze strony uczestników i gości Kongresu Inicjatyw Europy Wschodniej. 